SECTION 13. Geography. History. Oceanology. Meteorology.

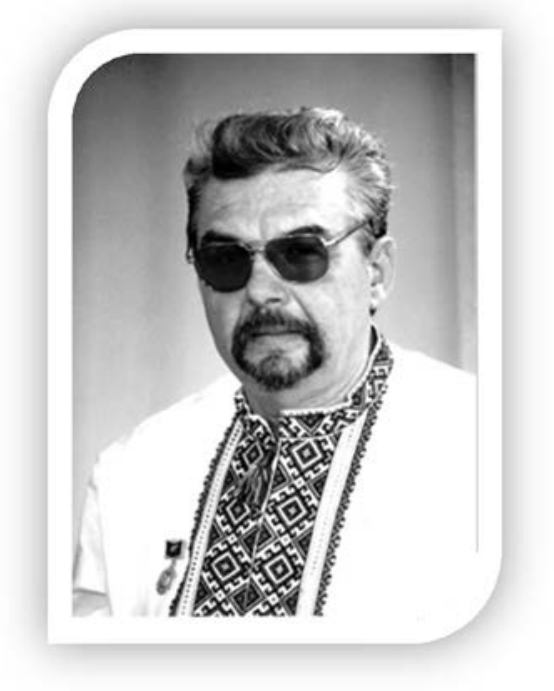

Tatarinov Sergey Iosifovich candidate of historical Sciences, associate Professor, Educational and Scientific Professional Pedagogical Institute of Ukrainian Engineering and Pedagogical Academy

\title{
THE INFLUENCE OF THE DISTRICT COUNCIL TO ACTIVITIES OF THE POLICE IN THE BAKHMUT DISTRIST AT THE END OF 19TH AND THE BEGINNING OF 20TH CENTURIES.
}

The influence of the district council to activities of the police in the Bakhmut distrist at the end of 19th and the beginning of 20th centuries. For the first time the principals of financing police by the elective district council (zemstvo) self-government of Bakhmut and its district (uezd), types of activity and functions of police were studies.

Keywords: budget, estimate, police-officer, policeman.

\section{ВЛИЯНИЕ ЗЕМСКИХ УЧРЕЖДЕНИЙ БАХМУТСКОГО УЕЗДА ДОНБАССА НА ДЕЯТЕЛЬНОСТЬ ПОЛИЦИИ В КОНЦЕ 19-НАЧАЛЕ 20 СТОЛЕТИЙ.}

Влияние земских учреждений Бахмутского уезда Донбасса на деятельность полиции в конце 19 - начале 20 столетий. Впервые исследованы принцииьы финансирования поличии земским самоуправлением Бахмута и уезда, формь деятельности и функичи полиции.

Ключевые слова: бюджет, смета, пристав, городовой.

За радянських часів історії поліції надавалося виключно політичне забарвлення як знаряддю боротьби з революціонерами.

У незалежній Україні зявилися праці, присвячені ролі і місцю поліції у суспільному устрою Россії [1].

Мета статті. Поліція у будь якій державі завжди була частиною карального, примусового аппарату влади, вмонтована у неї та повязана 3 загальнодержавною політикою. Як і місцеве самоврядування, місцеві органи МВС постійно реформують, шукають шляхи зміни фінансування. Досвід минулого має бути корисним.

Виклад основного матеріалу. В кінці 19 століття особливу увагу викликало фінансування поліції з бюджетів міст. Згідно з Законами міста повинні були надавати поліцейським Управлінням та пожежним командам приміщення 3 опаленням та освітленням, видавати чинам поліції та пожежної команди кошти на наймання квартир, постачати поліції продукти харчування, амуніцію, забезпечувати службовців 
поліцейських та пожежних команд медичним допомогою. Витрати на грошове утримання чинів поліції повинні були покриватися з державного казначейства, а участь міст в цих витратах дозволялася при наявності у бюджетах коштів. Міністерство внутрішніх справ покладало на Думи повне утримання міських поліцейських [2].

На хвилі пануючого в суспільстві негативного відношення до поліції Думи дивилися на поліцію як на тягар.

За кошторисом Бахмутське повітове земство вперше виділяло допомогу Бахмутському повітовому поліцейському управлінню у 1866 р. 800 рб.

Міністерство внутрішніх справ затвердило у 1890 р. штат поліції Бахмуту з 5 старших і 19 молодших чинів. Кожному з них виділялося в рік на обмундирування 25-30 рб. [3].

В 1896 році було асигновано 6798 рб., що складало 15\% річного бюджету міста, допомога казни на утримання поліцейського Управління в Бахмуті складала 399 рб. на рік. На квартирну платню, командировочні (роз'їзні) справнику повіту, його помічнику і поліцейським наглядачам (городовим) виділялося 900 рб. На нижніх чинів поліції (квартирні, допомога на лікування, придбання обмундирування, заробітна платня) було виділено 5808 рб. [4].

31896 р. обивателі Бахмуту в обов'язковому порядку несли "нічні караули" для попередження пожеж і охорони майна" [5].

В 1897 році штат міської поліції включав двох городових наглядачів (пристави), які одержували на наймання квартир по 200 рб. на рік. Дума на утримання низчих чинів поліції виділила 4596 рб. і на наймання квартир кожному по 2 рублі в місяць. 4 городові, що прослужили 7 і більше років, одержували допомогу за вислугу по 25 рб. на рік [6].

В 1899 році утримання особового складу поліції обходилося Думі в 4050 рб. (зарплата, допомога), на квартири старших чинів виділялося 500 рб., на квартири низчих чинів -1008 рб., на придбання амуніції, озброєння і провіанту 600 рб., на роз'їзди - 490 рб., окремо виділялося 100 рб. на лікування хворих поліцейських [7].

В 1910 році з міських доходів 122,3 тис. рб. на утримання поліції йшло 18,1 тис. рб. [8].

На початку сторіччя зростає чисельність правопорушень, що вимагало великих роз'їздів керівників поліції по повіту: справник повіту витрачав на цю мету більш ніж 20 рб. в місяць, його помічник до 12-15 рб. в місяць. Поліцейські наглядачі для поїздок по Бахмуту і околицям щомісячно витрачали до 5 рб. ( одна поїздка візником могла коштувати від 5 до 20 копійок) [9].

Правилами промислу візництва у Бахмуті передбачалися певні пільги поліцейським по використанню кінних прольоток для службової мети. Візники були зобов'язані доставляти в поліцію п'яних та бешкетуючих пасажирів, а поліцейські мали право безкоштовного проїзду по службових справах [10].

Під час епідемій чуми і холери на поліцейських Бахмуту покладався обов'язок подвірного обходу ділянок з метою виявлення хворих, доставка їх в карантинні бараки на околиці міста, охорона цих бараків, встановлення карантинних кордонів на в'їздах в місто. Іноді сил поліції не вистачало і тоді у Бахмут залучали поліцейських чинів з інших міст. Дума зняла квартиру за 67 рб. у міщанина Хургіної для 2 чинів поліції 3 Катеринослава у 1899 році під час епідемії холери [11].

На поліцію покладалося виявлення венеричних хворих, повій. Лікарському поліцейському огляду двічі на тиждень піддавалися дев'ять жінок в «Будинку терпимісті», жінок, що займалися проституцією під наглядом поліції (2 жінки - в 1895 р.). Поліція виловлювала «жінок в таємній розпусті» (25 жінок - в 1895 р.). Всього за рік 
кількість лікарсько -полицейских оглядів доходило до 1277. Проте, в цю цифру включалися не тільки повії, але і робітниці заводів Фарке, Скараманги, робочі -сезонники з Ростову - Нахічівані [11].

На початку XX ст. гостро постало питання телефонного зв'язку між станами i жандармськими пунктами. У вересні 1905 р. штаб-ротмістр Вячеславов просив дозволу у Думи на установку телефону в розшуковому жандармському пункті Юзівки «з метою швидкості зносин з нижніми чинами поліції в повіті". Управа категорично відмовила [12].

В 1901 -1902 роках міністерству внутрішніх справ і Державній Раді під головуванням Великого князя Михайла Олександровича довелося вводити нові штати поліції Бахмуту у зв'язку з тим, що "міська територія перевищувала 4054 десятин землі, населення досягло 25 тис. душ, число вулиць до 38 протяжністю 40 верст, торгових закладів понад 340, заводів і фабрик 17 з 1500 робітниками" [13].

Криза в промисловості 1900-1901 років і зростання політичної напруженості в суспільстві супроводжувалися зростанням загальної злочинності в Бахмуті (1896 -852 злочини, в 1899 році -2411 справ, в 1901 році - 4126 справ) [13]. [13].

Різко зросла міграція населення, видача поліцією паспортів з 49 до 1649 на рік

Різко збільшилося слідче навантаження поліції з 9057 в 1897 році до 10606 справ в 1902 р., "число дрібного розшукового листування зростає з кожним роком" [14].

В 1900 році власник слюсарної майстерний П. І. Павлов і дворянин Г. Шабельський створили «Союз руського народу», відкрили чайну тверезості у Народному Будинку [15].

В 1901 році єпископ Катеринославський і Таврійський Агапіт Вишневський виступив з антиєврейськими проповідями в бахмутських гімназіях [16].

У жовтні 1905 року натовп обивателів вчинив погром єврейських магазинів. Для придушення безладу прибули козаки і рота Павлоградського полку і... приєдналися до погромників. Були розгромлені магазини Абрамовича, Лейферова (після погрому зубожів та помер у 1908 р.), Марка Остроухова, Нахемія Гольдіна, Мойсея Ельберта. У Никитівці натовп розгромив будинок батька М. Рейзена, власника вугільного складу на станції [16].

Поліція контролювала страйк на копальні «Петро Великий» у 1905 році [17].

Протести робітників носили різноманітний характер 18.

В 1906 році поліція наводила лад під час погромів селянами Покровського економії Пшеничного, що призвело до збитків у 34 тіс.рб.

Певну інформацію містять повідомлення Відділення Російського телеграфного агенства Бахмуту, які друкували провідні газети Імперії у 1906-11 рр.

24 березня 1906 р. у телеграмі з Бахмуту повідомлялося про резонансну подію «Серед бахмутчан викликав велику сенсацію арешт багача Міленкова, в якого знайдений склад чорносотенних відозв, що закликали до биття євреїв і інтелігентів». Навіщо це було потрібно Назарію Міленкову, власнику цегляних та вапнякових заводів, невідомо... 7 червня 1906 р. на Донецькому содовому заводі у Лисичанську невідомі зловмисники кинули через вікна в квартиру заводських майстрів динамітні патрони. Вибухом пошкоджена квартира, але мешканці не постраждали. Поліція вважала цей замах помстою звільнених робітників. У телеграммі з Бахмуту 8 червня 1906 р. повідомлялося: « У Донецькому басейні на копальнях і заводах щодня відбуваються мітинги, що розганяються козаками. Страйки на вугільних копальнях Горловки припинилися. Деякі вимоги робітників задоволені». 13 червня 1906 р. газета «Русское слово» повідомляла що поліція Юзівки затримала неповнолітніх хуліганів, що розбили у Преображенській церкві икону 3 метою спровокувати єврейський погром. «Полиция объявляет, что 
надругание над святыней совершено не евреями как утверждали, а русскими, предаваемыми

суду».

Газета «Новое время» 16 липня 1906 р. писала, що у Донецький басейн прибув каральний поїзд, що складається 333 вагонів, серед яких знаходяться вагони для арештантів, санітарні і допоміжні з матеріалами, інструментами на випадок псування колії. У поїзді були гармати і кулемети. 7 серпня 1906 р. у Бахмут прибув французький посол Бомпар. Приїзд його був повязаний з подіями, що сталися в Донецькому басейні, коли під час страйку і затоплення шахт постраждали французи і бельгійці, як акціонери гірничих підприємств. Бельгійці пред'явили до російського уряду позов за збитки. 24 вересня 1906 р. у Бахмуті зранку відбувалися розкопки зруйнованого від вибуху бомби будинку удови Дмітрієвської. 3 маси уламків витягнули труп чоловіка, динаміт, жерсть, соціал-демократичну літературу. Поліція заарештувала молоду інтелігентну дівчину років 16-ти і чоловіка. Але він втік. 9 жовтня 1906 року у газеті «Русское слово» повідомлялося, що у Юзовці поліція заарештувала в конспіративній квартирі 13 терористів-"експроприаторів". При обшуку знайдений друкарський верстат. бланки, списки і 600 рб.

11 лютого 1907 р. невідомі зробили 5 пострілів у директора Дружківського заводу француза Раймона, який у фаетоні їхав додому ввечері. Від поранення у голову директор помер.

9 червня 1907 р. поліція затримала фальшувальників 3 рубльових асигнацій, вилучила револьвер та патрони.

17 червня 1907 р. у маєтку А.Ауербаха (ртутна копальня, Микитівна) опівдні штабс-капітан герой русько-японської війни Македонський вбив з браунінга свою тещу та іiі сина. За три дні до цього він був у гостях та підпалив будинок гласного земства Смєкалова. Будинок повністю згорів. «Героя» заарештували та стали встановлювати причини вчинення злочинів.

24 червня 1907 р. у Бахмуті до аптеки Співака увірвалися 2 «експропріатори» та стали вимагати гроші. Співак зчинив галас, один з грабіжників був затриманий, у нього вилучили револьвер та революційну літературу.

30 червня 1907 р. біля селища Лозова-Павлівка шестеро невідомих напали на довіреного борошномельного Товариства, що везли велику суму грошей. Схопивши мішок $з$ двома тисячами рублів злочинці не звернули увагу на інший мішок, в якому лежало 15 тис. р. і втекли.

В 1909 році серед гучних кримінальних справ було вбивство дворянина Шабельського чоловіком його коханки .

16 червня 1909 р. поліцією арештовані і поміщені під варту німецький підданий Волер, селянин Федотов і міщанин Башликов. Вони ходили вночі по місту і відкривали пивні і бакалійні лавки, при формі Волер рекомендувався чиновником особливих доручень $з$ Петербургу для ревізії торгівельних документів. Під час «перевірки документів» спільники Волера «відкликали у бік господарів і радили їм давати ревізорові хабар».

«Голос Москви» 14 вересня 1909 року писав, що вночі шість грабіжників напали на садибу Камінського в Бахмутскому повіті. Не знайшовши власника, що виїхав на станцію Лоскутовка, вони попрямували туди i вбили декількома пострілами Камінського, поранили його дружину і забрави гроші, папери та деякі речі.

У рапортах повітового справника є відомості про напади на священників. У 1908 році у Авдотьїно було вбито священника Богдановича. Біля станції Попасна Іван 
Самойлов і Костянтин Охотнік напали на священника села Троїцьке [19]. У 1909 році у звязку зі стратами революціонерів священники масово відмовлялися бути присутніми, протестуючи проти рострілів та повішень робітників, селян, студентів. Поліція навіть негласно стежила за священниками, яких вважала неблагонадійними [20]. В 1911 році під наглядом перебуав священник с. Григор’ївка Василь Логвинович.

Поліція переслідувала різні релігійні течії, в 1909 році викрила у селі Луганське секти стафановців та «малапутів» [21].

Огляд 16 номерів газети «Бахмутський листок» у квітні 1912 р. вказує на цілий букет кримінальних злочинів, якими займалася поліція [22].

Поліція розкрила підпал контори Донецької Трудової Артілі 7 січня 1912 р. Підозрювали шурина голови Правління К.Алєксєєва та його дружину Фоміну у навмисному підпалі з метою отримати страховку. Алєксєєв пояснював, що чистив спиртом калоші і спирт несподівано спалахнув, він злякався і втік до церкви. Суд виправдав пізозрюваних.

У окружному суді слухалася розкрита повітовою поліцією справа Кононенка, Попова,Кулика, Тер-Давидова, Мусалова, Шаргородського, Жабченко та братів Соловійових у фальшуванні монети у Нахічевані, працювали нав Петровських заводах повіту.

Сліпий жебрак Кулик у Грушевій Балці шукав покупців на фальшиві срібні рублі та золоті імперіали (по 45 коп. и 3 рублі), возив у Нахічевань 3 січня 1911 р., був анонімний лист до поліції. У Ростові у Мосоєлова у лавці вилучили 300 рублів та 34 імперіала. Винні отримали від 8 до 14 років каторги.

Поліція викрила власника шорної майстерні у Бахмуті, який розсилав по залізниці «вироби» (мішки з вугіллям) накладеним платіжом на міфічних адресатів, реєстрував документи у казначействі, отримував гроші. Утік від поліції.

На ртутній копальні пристав Щербина затримав злочинця Шевцева, який шантажував С.О. Ауербаха і вимагав 17,5 тис. рб., пограбував торговця С.Криволапова та пекарню Асмакових у Горлівці. Мав підробний звільнювальний Білет 21 Муромського полку, видавав себе за студента-політехніка.

Начальник 3 дільниці повіту розглянув справу групи циган про порушення тиші у горомадському місті. Бійка відбулася через те, що циган віддав у дружини на місяць свою 14 річну доньку за 2 коней вартістю 140 рб. Доньку відмовилися повертати. Пристав Караченцов затримав табір циган. Начальник поліції виправдав дії пристава, зобовязав повернути коней.

Поліція розслідувала випадкові смерті, пропажі осіб, виробничі травми. 17 квітня у лісі біля Государєва Байрака знайдено тіло мертвої жінки -Мотрони Познякової 17 років, яка йшла на пошуки роботи у Микитівці. У Софієвці Торсько-Олексійовської волості потонув у ямі вдома дворічний Яків. У Гришино загадково померла 20 річна Віра Горанкіна. Пропала без вісті служниця пімічника справника Д.К.Борткевича 25 річна Феолосія Литовкина. Робітник конфетної фабрики Флітельмана у Дмитровці (Костянтинівка) Гаврило Слюсарєв «во время попойки скоропостижно скончался». У с. Олексіївка Сантуринської волості Ганна Пивнева вчаділа від закритої труби.

Поліція не завжди реагувала на порушення громадського порядку. Біля будинку Шароєвської на Харківській вулиці відбулася бійка. Було пробито голову палкою Спостерігачі звернулися до городового 14 ділянки, але він не зрушив з місця, не затримав нападника.

У зв'язку з оголошенням війни Німеччиною Росії 23 липня 1914 р. в Бахмуті відбулися монархічні заворушення, розбиті вітрини, повалено стовпи ліхтарів, пошкоджено майно електричної станції на 1060 рб. (там працювали німці-інженери?). Дума відмовилася відшкодувати збитки [15]. 
На поліцію була покладена функція збору податків в міську казну [23] по окладних листах (964) квартирного і промислового збору на загальну суму 21 тис. рб., що складало до 30-40\% річних надходжень до бюджету міста. Потрібно було промисловий збір отримувати з сотень магазинів і лавок, питних закладів, візників, ремісників [24].

В період I Світової війни погіршилася робота поліції по стягненню земських зборів. У вересні 1915 року віце-губернатор О. Тецнер указував на «бездіяльність пристава Бахмуту Савіна, його помічника Карлова, з вини яких недоїмка губернського збору склала 389400 рб. і окладного збору з приватних будинків 777933 рб.». Справник повіту просив накласти на винних дисциплінарне стягнення, а пристав виправдовувався

- "багато недоїмщиків призвані на війну" [24].

Траплялося перевищення чинами поліції своїх повноважень.

Для промисловців проблемою стали незаконні побори поліції. Губернський окружний фабричний інспектор в січні 1902 року писав: "банкрутствам в нашому повіті сприяє не тільки загальний застій в торгівлі, але і зграя грабіжників поліцейських урядовців на чолі з їх головним отаманом, що сформована справником Шишковим" [25].

Анонім I.I. Правда писав окружному фабричному інженеру, що справник «польський дворянин, блискучий мундир артилерійського офіцера проміняв, на поліцейський, "має в Бахмуті кращий будинок, а прибув в повіт мало не в залатаних шароварах", «помічники навіть в єврейських хедерах вчилися і проміняли свою стародавню іудейську віру на православну, встигли придбати копальні» [25].

Шишков вимагав незаконно вносити поліцейському Управлінню 30 тис. рб. щорічно на канцелярські витрати. Фабричні пристави вимагали по 5 - 6 тисяч в рік, "все це відволікає їх від фабричних заворушень" [26].

В січні 1912 року стався конфлікт між вуличними нічними сторожами на Великій Харківській Д. Пащенко, Є. Дедовим і городовим Н. Бондаренком, який побив сторожів батогом [27].

В жовтні 1913 року міщанин М. Гиков скаржився на стражника I. Резникова i городового І. Кострому за побиття [28].

Скандалом став штраф у 150 рб., накладений на кількох відомих купців за азартні ігри у Комерційному клубі Бахмуту [29].

Напередодні та у період Світової війни різко зростає чисельність поліційних чинів, вводяться нові посади та структури.

Створюється кінно-поліцейська варта Юзовського району. В повіті наглядали за порядком 21 пристав, 18 поліцейських наглядачів (3 в Юзівці), 21 районний наглядач (9 3 них в Юзівці) [30].

Це було пов'язано з наростаючою революційною напруженістю в в суспільстві.

Висновки і перспективи подальших досліджень. Аналіз архівних джерел позволяє зробити висновок, що утримання міської поліції Бахмуту та посадових осіб у повіті складало значну частину кошторисах Думи та земства. Одночасно, установи самоврядування жодним чином не могли впливати, втручатися у дії поліції. Подальшого вивчення потребує склад справ, які розслідувала поліція, іiі вплив на громадський порядок у повіті.

\section{Література}

1. Ярмыш А.Н. Наблюдать неотступно. Административно-полицейский аппарат и органы политического сыска царизма в Украине в конце XIX - начале XX в. - К. 1992. 186 с.; Історія держави і права: Академічний курс. /За ред. В.Тація, А. Рогожина. - К. 
2000. - 648 с.; Ярмиш О.Н. Каральний апарат самодержавства в Україні в кінці ХІХ - на початку ХХ ст. - Харків, 2001, - 288 с.; Холод Ю.А. Загальна поліція Російської імперії в Україні в 1862-1905 рр. Дис. канд. юрид. наук. - Харків. Нац. ун-т внутр. справ, 2002.

2.Анучин Е.И. Исторический обзор административно-полицейских учреждений России с учреждения о губерниях и до последнего времени. - СПб.:Тип. МВД, - СПБ, 1872. - 239 с.; Елистратов А.И. Должностное лицо и гражданин //Вопросы административного права. - М.,1906; Елистратов А.И. Основные начала административного права. - М.1917; Ефремова Н.Н., Немытина М.В. Местное самоуправлениє и административная юстиция в России (1864-1917 гг.) // Государство и право. - 1994. - №3. - с. 126-133; Жукова А.А. Проблеми взаимодействия властных структур и земского самоулравления в пореформенной России, 1864-1918, - М.2000.

3.Обзор Екатеринославской губернии за 1890 г. Приложение к нижайшему докладу Е.И.В. Екатеринославского губернатора. - Екатеринослав, 1889.

4. РГИА. - ф. 573. - оп. 30. - д. 1007. Смета доходов и расходов по Бахмуту за 1895 год; РГИА. - ф. 573. - оп. 30. - д. 1008. Смета доходов и расходов по Бахмуту за 1896 год

5. РГИА. - ф. 573. - оп.30. - д. 1010. Отчет Бахмутской городской управы за 1896 год.

6. Отчет городской управы За 1897 г. -Бахмут, 1898. - 127 с.

7. РГИА. - ф. 1288 - оп. 6 - д. 84. Смета доходов и расходов Бахмута за 1899 год; РГИА. - ф. 1288. - оп. 6. - д. 84. Отчет Бахмутской городской управы за 1899 г.

8. Отчет Бахмутской городской управы за 1910 год. - Бахмут, 1911. - 105 с.

9. Журналы XXXIV очередного Бахмутского уездного земского собрания. Бахмут, 1900. -275 С.; Журналы XXXV очередного Бахмутского уездного земского собрания. - Бахмут,1901. - $244 \mathrm{C}$.

10. Отчет Бахмутской городской управы за 1895 г. - Бахмут, 1896. - 127 с.

11. РГИА. - ф.1284. - оп. 194. - д. 61. Отчет Екатеринославского губернатора за 1910 год со сведениями о розыскных органах в губернии и холерной эпидемии 1910 г.; Завада Л.В., Татаринов С.Й., Блэднов В.П. Нариси земської медицини Бахмутського повіту. - Артемівськ, 2011, - 86 с.

12. Журналы XXXIII очередного Бахмутского уездного земского собрания. Бахмут, 1899. - 423 C.

13. РГИА. - ф.1149. - д. 107. Дело Департамента законов государственного совета об учреждении в Бахмуте должности пристава и его помощников, 1901 г.

14. Отчет Бахмутской городской управы за 1901 г. - Бахмут, 1902. - 127 с. ; Отчет Бахмутской городской управы за 1902 г. - Бахмут,1903. - 115с.

15. Бровкин Л.В., Татаринов С.И., Шаталин А.В. История правоохранительных органов Бахмута-Артемовска. - Артемовск, 2007, - 72 с.

16. Казаков А.Л., Татаринов С.И., Федяев С.В. От «черты оседлости» к холокосту. - Артемовск, 2003, - 82 с.

17. Дн.ОГА. - Ф.11. - оп.1. - д.480. Дело о забастовке на шахте «Петр Великий».

18. Дн.ОГА. - Ф.23. - оп. 1. - д.3. Переписка с Екатеринославским окружным фабричным инспектором.

19Дн.ОГА. - Ф. 11. - сч. оп. 1. - д. 559. Донесения уездных исправников, 1908 г.

20.Дн.ОГА. - Ф.11сч. - оп.1. - д. 1032. Донесения уездных исправников, 1909г.

21. Татаринов С.Й., Тутова Н.О. Історія православя Донеччини. - Артемівськ, 2010, - 236 c.

22. Бахмутский листок. Ежедневная газета: Издатель А.А.Кашникова. - Бахмут, 1912, - 12-29 апреля.

23.Анучин Е.И. Исторический обзор административно-полицейских 
учреждений России с учреждения о губерниях и до последнего времени. - СПб.:Тип. МВД, - СПБ, 1872. - 239 с.; Инструкция полиисйским урядникам 28 июля 1887 годи //Арефа Н.И. Права и обязанности полицейских урядников, стражников. приставов и прочих чинов городской и уездной полиции. - СПб. 1891. с. 115 - 123; Положение о мерах к охранению государственного порядка и общественного спокойствия 14 августа 1881 // Свод законов Российской империи.:Изд. 1892 г. - т. 15; Тарасов И.Т. Лекции по полицейскому (адмннистратпвному) праву. - М.: Университетская тип. - 1908. - т. і. 251 с.; Гессен В.М. Лекции по полицейскому праву.: Изд. студен-тов 1907-1908 гг. - Вып. І. - СПб.1908. - 196, - с.; КурчинскиЙ М. Реформа земских и городских финансов /Городское дсло, - 1912. - №3. - с 165-175.

24. Дн.ОГА. - ф.20. - оп.1. - д.135. Бездеятельность Бахмутского пристава по взиманию земских сборов; Смета Бахмута на 1910 год. - Бахмут,1910. - 121 С.; Смета Бахмута на 1911 год. - Бахмут, 1911. -121 С; Смета Бахмута на 1912 год. - Бахмут,1912. $-121 \mathrm{c}$.

25.Дн.ОГА. - ф.20. - оп.1. - д.124. О вымогательстве пристава Энбрехта.

26.Дн.ОГА. - ф.23. - оп.1. - д.З. Жалоба на исправника Шишкова.

27.Дн.ОГА. - Ф.20. - оп.1. - д.63. Дело по жалобе Пащенко на городового Бондаренко.

28. Дн.ОГА. - Ф. 11сч. - оп.1. - д. 1302. Донесения уездных исправников, 1915г.; Дн.ОГА. - Ф.20. - оп.1. - д.89. Жалоба Максима Гикова.

29.Дн.ОГА. - ф.11. - оп.1. - д.1032. Азартные игры в Коммерческом клубе.

30. Дн.ОГА. - ф.11. - оп.1. - д.1302. Донесения уездного исправника о кражах и убийствах 1915 г.; Екатеринославский адрес-календарь на 1915 год. - Екатеринослав, 1914; Справочная книга Екатеринославской губернии за 1916 год. - Екатеринослав, 1915. 